\title{
Analisis Sikap, Norma Subjektif, dan Niat Beli Produk Kosmetik Halal pada Konsumen Muslimah di Surabaya
}

\author{
Agnesya Balques, Bustanul Arifin Noer, dan Varah Nuzulfah \\ Departemen Manajemen Bisnis, Fakultas Bisnis dan Manajemen Teknologi (ITS) \\ e-mail: bus4arifin@gmail.com
}

\begin{abstract}
Abstrak-Industri kosmetik halal diprediksi mengalami pertumbuhan sebesar $10 \%$ dari tahun 2015-2020. Fenomena tersebut membuat perusahaan kosmetik berlomba-lomba untuk memberikan label halal pada produknya. Perusahaan tidak dapat bergantung hanya pada kehalalan produknya jika ingin bersaing dan bertahan dalam industri kosmetik halal. Perusahaan perlu mengetahui lebih jauh faktor apa saja yang dapat mempengaruhi niat beli produk kosmetik halal agar dapat memenangkan persaingan sehingga, penelitian ini dilakukan untuk mengetahui pengaruh halal awareness, religiosity, sertifikasi halal, dan pemasaran halal terhadap sikap konsumen serta pengaruh norma subjektif dan sikap terhadap niat beli produk kosmetik halal. Penyebaran kuesioner dilakukan dengan menggunakan metode online dan offline kepada 273 wanita karir beragama Muslim berusia 21 50 tahun yang merupakan pengguna aktif kosmetik di Surabaya. Penelitian ini menggunakan analisis Structural Equation Modeling (SEM) untuk menguji hipotesis. Temuan dari penelitian ini adalah terdapat pengaruh signifikan antara halal awareness, religiosity, sertifikasi halal, dan pemasaran halal terhadap sikap serta norma subjektif dan sikap berpengaruh signifikan terhadap niat beli produk kosmetik halal.
\end{abstract}

Kata Kunci-Kosmetik Halal, Halal Awareness, Religiosity, Sertifikasi Halal, Pemasaran Halal, Norma Subjektif, Sikap, Niat Beli Konsumen, Structural Equation Modeling.

\section{PENDAHULUAN}

$\mathrm{P}$ ASAR kosmetik global diperkirakan akan mencapai nilai US \$429 miliyar pada tahun 2022 [1]. Pertumbuhan industri kosmetik turut terjadi di Indonesia. Pada tahun 2011 hingga 2015, industri kosmetik di Indonesia telah bertumbuh secara positif dengan rata-rata pertumbuhan setiap tahunnya $13,03 \%$ [2]. Mengingat bahwa $87 \%$ penduduk Indonesia beragama Islam, permintaan produk halal di Indonesia terus meningkat tak terkecuali untuk produk kosmetik. Kosmetik halal adalah kosmetik yang tidak terkontaminasi dengan babi, dan hewan ternak yang disembelih tidak sesuai dengan syariat Islam serta membahayakan tubuh seperti merkuri dan hidroquinon [3].

Industri kosmetik halal diprediksi akan meningkat ratarata sebesar 10\% pada tahun 2015-2020 [4]. Lebih lanjut, Indonesia masuk ke dalam sepuluh besar Global Islamic Economy Indicator (GIEI) [5]. Kualitas ekonomi Islam pada industri kosmetik yang cukup baik, berbanding terbalik dengan pangsa pasar kosmetik yang dikuasai oleh merek multinasional. Akibatnya, sektor kosmetik dan farmasi menjadi subyek pengawasan yang lebih besar oleh para Muslim karena terdapat kecurigaan bahwa banyak merek internasional menggunakan enzim yang diekstrak dari daging babi [6]. Besarnya potensi pasar produk kosmetik halal, dimanfaatkan oleh produsen kosmetik lokal dan multinasional yang menyasar konsumen muslim dengan strategi membuat produk kosmetik halal. Hal ini sejalan dengan pernyataan bahwa perusahaan yang memenuhi persyaratan syariah Islam dapat meningkatkan pelanggan [3]. Namun terdapat perbedaan pendapat yang menyatakan bahwa pengaruh agama akan bervariasi bagi setiap Muslim dan tidak sama pada dua individu [6].

Penelitian ini memodifikasi model penelitian terdahulu [3][7]. Modifikasi model dilakukan karena adanya keterbatasan penelitian terdahulu yaitu tidak adanya variabel moderator seperti variabel sikap maka dari itu, penelitian ini akan menambahkan variabel sikap sebagai variabel moderator. Secara spesifik penelitian ini fokus pada niat beli produk kosmetik halal yang dipengaruhi oleh sikap dan norma subjektif serta sikap yang dipengaruhi oleh halal awareness, religiosity, sertifikasi halal, dan pemasaran halal.

\section{TINJAUAN PUSTAKA}

\section{A. Theory Reasoned of Action (TRA)}

Dasar teori yang digunakan dalam penelitian ini adalah Theory Reasoned of Action karena TRA merupakan model yang valid dalam memprediksi niat beli. Dalam TRA, niat individu merupakan fungsi dari dua penentu dasar, yaitu faktor personal (sikap) dan pengaruh social [3]. Faktor personal merupakan cerminan dari keyakinan perilaku yang menonjol pada individu yang disebut sikap [8]. Faktor pengaruh sosial merupakan persepsi individu bahwa terdapat tekanan sosial yang menempatkan dirinya untuk melakukan atau tidak melakukan perilaku yang bersangkutan yang disebut faktor norma subjektif [3]. Norma subjektif merupakan sejauh mana seorang individu merasakan bagaimana orang lain menyetujui tindakan individu dalam perilaku tertentu [8].

\section{B. Halal Awareness}

Awareness merupakan kemampuan untuk memahami, merasakan, dan menyadari peristiwa dan benda-benda [9]. Halal merupakan istilah Arab yang memiliki arti “diperbolehkan". Dalam bahasa Arab, halal mengacu pada sesuatu yang diperbolehkan dalam Islam. Lawan kata dari kata halal adalah haram. Halal dan haram sering digunakan untuk menggambarkan produk makanan, minuman, obat, kosmetik, dan lain-lain. Sesuatu yang halal dan haram diputuskan sesuai dengan Al-Qur'an dan Hadist. Dapat disimpulkan halal awareness merupakan kesadaran konsumen akan kehalalan sebuah produk. 


\section{Religiosity}

Religiusitas merupakan tingkat kepercayaan individu dalam agama yang dianutnya [10]. Terdapat dua tipe religius yaitu intrinsik dan ekstrinsik. Individu dengan religius intrinsik menganggap bahwa agama merupakan fokus utama dalam kehidupan. Individu ini memperlihatkan perhatian yang lebih besar terhadap moral, disiplin, dan tanggung jawab dibandingkan dengan religius ekstrinsik. Individu dengan religius ekstrinsik cenderung menggunakan agama untuk kepentingan pribadi [11]. Tingkat religiusitas konsumen berpengaruh positif terhadap sikap terhadap produk Halal [6].

\section{Halal Certification}

Sertifikasi halal mengacu pada pengakuan resmi dari proses persiapan, pemotongan, pembersihan, penanganan, dan praktik manajemen yang relevan lainnya oleh organisasi yang dibentuk contohnya seperti MUI di Indonesia [9]. Di Indonesia, sertifikasi kehalalan produk makanan, minuman, kosmetik, obat, dan sejenisnya ditangani Lembaga Pengkajian Pangan, Obat-Obatan, dan Kosmetika Majelis Ulama Indonesia (LPPOM MUI). Sertifikasi dan logo halal pada produk tidak hanya menjamin umat Muslim terkait dengan apa yang dikonsumsi sesuai dengan hukum Islam, namun juga memberikan keyakinan kepada produsen bahwa produk telah memenuhi standar halal [12]. Sertifikasi halal mewajibkan proses kontrol kualitas untuk mengawasi pelaksanaan produksi dan menjamin standar kualitas.

\section{E. Halal Marketing}

Dalam pemasaran Islam atau pemasaran halal, agama mempengaruhi pilihan konsumen. Pemasaran Islam adalah daerah yang relatif baru dari studi dalam pemasaran, meskipun praktik hukum syariah yang telah diterapkan untuk waktu yang lama. Pemasaran halal mengikuti hukum, prinsip-prinsip dan pedoman Islam dalam merancang pemasaran strategis, berkomunikasi dan memberikan produk dan layanan kepada pelanggan [13]. Dalam menjual layanan atau produk halal, pemasar lebih disarankan untuk melakukan branding dibandingkan komunikasi pemasaran untuk meningkatkan kesadaran akan sertifikasi dan merek halal pada produknya [14].

\section{METODOLOGI PENELITIAN}

Penelitian ini menguji 6 hipotesis dengan model penelitian ditunjukkan Gambar 1 diadopsi dari penelitian terdahulu [3][7]. Keenam hipotesis yang diuji adalah:

H1. Halal awareness berpengaruh positif pada sikap konsumen terhadap produk kosmetik halal.

H2. Religiosity berpengaruh positif pada sikap konsumen terhadap produk kosmetik halal.

H3. Halal certification berpengaruh positif pada sikap konsumen terhadap produk kosmetik halal.

H4. Halal marketing berpengaruh positif pada sikap konsumen terhadap produk kosmetik halal.

H5. Norma subjektif berpengaruh positif pada niat beli konsumen terhadap produk kosmetik halal.

H6. Sikap berpengaruh positif pada niat beli produk kosmetik halal.

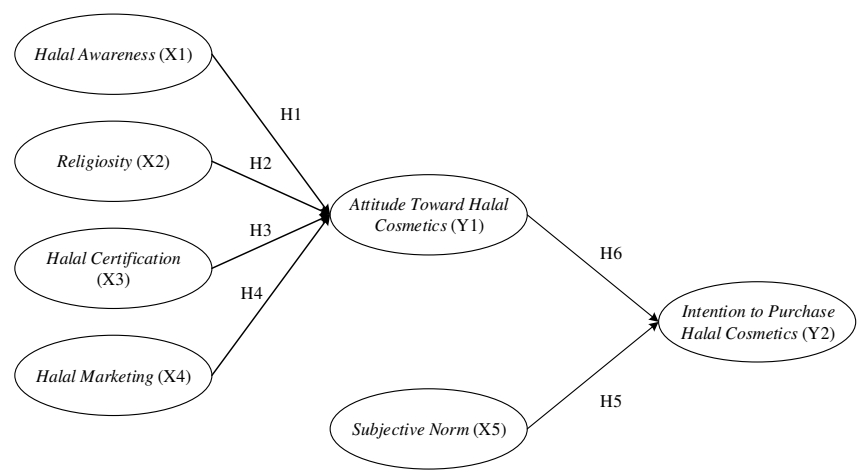

Gambar 1. Model penelitian pengaruh halal awareness, religiosity, halal certification, dan halal marketing terhadap sikap konsumen, serta pengaruh norma subjektif dan sikap terhadap niat beli produk kosmetik halal.

Pengujian model menggunakan metode structural equation modelling (SEM). Responden penelitian ini adalah wanita yang bekerja formal, berusia 21 hingga 50 tahun, beragama Islam, minimal menggunakan tiga produk kosmetik, dan berdomisili di Surabaya. Penelitian ini mengumpulkan data melalui penyebaran kuesioner secara offline dan online di Surabaya dengan metode convenience sampling. Penyebaran offline dilakukan dengan menggunakan print out kuesioner dengan cara membagikan kepada wanita karir yang bekerja di perkantoran seperti di bank, hotel, supermarket, pusat perbelanjaan, dan kantor pemerintahan. Penyebaran online dilakukan dengan menggunakan Google Form melalui media sosial dan instant messenger.

Kuesioner terdiri dari tiga bagian. Bagian pertama, berisi pertanyaan screening, demografi, dan usage kosmetik. Bagian kedua berupa pernyataan inti dan bagian ketiga berupa kritik dan saran responden untuk peneliti. Kuesioner penelitian menggunakan skala Likert 5 poin. Pengumpulan data dilakukan mulai bulan April 2017 hingga Mei 2017 dan terkumpul 273 kuesioner lolos screening, yang kemudian dilakukan analisis data.

\section{HASIL ANALISIS DATA DAN DISKUSI}

\section{A. Analisis Deskriptif Demografi}

Demografi responden terdiri dari usia, pendidikan terakhir, status pernikahan, jenis pekerjaan, dan pendapatan per bulan. Dari 273 respon, 184 responden berusia 21 hingga 30 tahun, sedangkan usia 31-40 tahun dan 41-50 tahun masing-masing sebanyak 69 dan 20 responden. Pendidikan terakhir responden terdiri dari sekolah menengah hingga magister. Sebanyak 97 responden memiliki pendidikan terakhir sekolah menengah, 36 responden memiliki pendidikan terakhir diploma, 128 responden memiliki pendidikan terakhir sarjana, dan 12 memiliki pendidikan terakhir magister. Berdasarkan status pernikahan, sebanyak 138 responden sudah menikah, 129 responden belum menikah, dan 6 responden bercerai.

Jenis pekerjaan responden sebanyak 20 responden merupakan pegawai negeri sipil, 201 responden merupakan pegawai swasta, 20 responden merupakan pagawai BUMN. Responden penelitian didominasi oleh masyarakat golongan ekonomi menengah. Responden dengan pendapatan kurang dari $\mathrm{Rp} 3.200 .000$ sebanyak 88 responden, pendapatan $\mathrm{Rp}$ 3.300 .000 - Rp 5.000.000 sebanyak 144 responden, 
pendapatan Rp 5.100.000 - Rp 7.500.000 sebanyak 27 responden, pendapatan Rp 7.600.000 - Rp 10.000.000 sebanyak 9 responden, dan lebih dari Rp Rp 10.000.000 sebanyak 5 responden.

\section{B. Analisis Model Penelitian SEM}

Penelitian ini melakukan uji model penelitian SEM menggunakan respesifikasi model dengan metode eliminasi untuk memperoleh model penelitian yang paling sesuai dengan data. Metode eliminasi dilakukan dengan mengurangi indikator tertentu untuk memperoleh nilai factor loadings yang memenuhi nilai minimum.

Tabel 1.

Uji validitas dan reliabilitas

\begin{tabular}{|c|c|c|c|c|}
\hline Konstruk & Indikator & $\begin{array}{c}\text { Factor } \\
\text { Loading } \\
(\geq 0.60)\end{array}$ & $\begin{array}{c}\text { Cronbach's } \\
\text { Alpha } \\
(\geq 0.60)\end{array}$ & $\begin{array}{c}\text { Construct } \\
\text { Reliability } \\
(\geq 0.70)\end{array}$ \\
\hline \multirow{9}{*}{$\begin{array}{c}\text { Halal } \\
\text { Awareness } \\
\text { (HA) }\end{array}$} & HA1 & 0,74 & \multirow{9}{*}{0,910} & \multirow{9}{*}{0,910} \\
\hline & HA2 & 0,76 & & \\
\hline & HA3 & 0,77 & & \\
\hline & HA4 & 0,72 & & \\
\hline & HA5 & 0,77 & & \\
\hline & HA6 & 0,74 & & \\
\hline & HA7 & 0,68 & & \\
\hline & HA8 & 0,73 & & \\
\hline & HA9 & 0,62 & & \\
\hline \multirow{5}{*}{$\begin{array}{l}\text { Intrinsic } \\
\text { Religiosity } \\
\text { (R) }\end{array}$} & $\mathrm{R} 1$ & 0,75 & \multirow{5}{*}{0,865} & \multirow{5}{*}{0,867} \\
\hline & R7 & 0,76 & & \\
\hline & R9 & 0,82 & & \\
\hline & R11 & 0,77 & & \\
\hline & R16 & 0,65 & & \\
\hline \multirow{7}{*}{$\begin{array}{l}\text { Extrisic } \\
\text { Religiosity } \\
\quad(\mathrm{R})\end{array}$} & $\mathrm{R} 2$ & 0,67 & \multirow{7}{*}{0,896} & \multirow{7}{*}{0,897} \\
\hline & $\mathrm{R} 4$ & 0,81 & & \\
\hline & R14 & 0,72 & & \\
\hline & $\mathrm{R} 15$ & 0,71 & & \\
\hline & $\mathrm{R} 17$ & 0,76 & & \\
\hline & $\mathrm{R} 18$ & 0,76 & & \\
\hline & $\mathrm{R} 20$ & 0,75 & & \\
\hline \multirow{5}{*}{$\begin{array}{l}\text { Sertifikasi } \\
\text { Halal (SH) }\end{array}$} & SH1 & 0,80 & \multirow{5}{*}{0,883} & \multirow{5}{*}{0,886} \\
\hline & $\mathrm{SH} 2$ & 0,77 & & \\
\hline & SH3 & 0,64 & & \\
\hline & SH4 & 0,84 & & \\
\hline & SH5 & 0,84 & & \\
\hline \multirow{7}{*}{$\begin{array}{l}\text { Halal } \\
\text { Marketing } \\
(\mathrm{HM})\end{array}$} & HM1 & 0,78 & \multirow{7}{*}{0,875} & \multirow{7}{*}{0,878} \\
\hline & HM2 & 0,61 & & \\
\hline & HM3 & 0,79 & & \\
\hline & HM4 & 0,78 & & \\
\hline & HM5 & 0,71 & & \\
\hline & HM6 & 0,60 & & \\
\hline & HM7 & 0,69 & & \\
\hline \multirow{3}{*}{$\begin{array}{l}\text { Norma } \\
\text { Subjektif } \\
\text { (NS) }\end{array}$} & NS1 & 0,82 & \multirow{3}{*}{0,872} & \multirow{3}{*}{0,876} \\
\hline & NS2 & 0,88 & & \\
\hline & NS3 & 0,82 & & \\
\hline \multirow{3}{*}{ Sikap (S) } & S1 & 0,83 & \multirow{3}{*}{0,895} & \multirow{3}{*}{0,894} \\
\hline & $\mathrm{S} 2$ & 0,86 & & \\
\hline & $\mathrm{S} 3$ & 0,89 & & \\
\hline \multirow{5}{*}{$\begin{array}{l}\text { Niat Beli } \\
\text { (NB) }\end{array}$} & NB1 & 0,77 & \multirow{5}{*}{0,905} & \multirow{5}{*}{0,906} \\
\hline & NB2 & 0,77 & & \\
\hline & NB3 & 0,82 & & \\
\hline & NB4 & 0,87 & & \\
\hline & NB5 & 0,81 & & \\
\hline
\end{tabular}

Dengan menghilangkan empat indikator dari variabel intinsic religiosity yaitu R5, R6, R12, dan R19 serta empat indikator dari variabel extrinsic religiosity yaitu R3, R8, $\mathrm{R} 10$, dam R13. Data dianalisis mengunakan confirmatory factor analysis (CFA) yang diolah dengan software AMOS untuk menguji validitas melalui nilai factor loadings serta uji reliabilitas dengan melihat nilai cronbach's alpha dan construct reliability. Variabel penelitian dikatakan valid apabila nilai factor loadings lebih dari 0.60, cronbach's alpha lebih dari 0.60, dan construct reliability lebih dari 0.70 . Tabel 1 menunjukkan bahwa data memenuhi uji validitas dan reliabilitas.

Uji model fit dilakukan menggunakan software AMOS untuk mengukur goodness of fit (GOF). Nilai yang memenuhi adalah Chi-Square, parsimonious index goodness-of-fit, dan parsimonious normed fit index. Terdapat beberapa kriteria GOF yang belum memenuhi kriteria cut-off-value, sehingga perlu dilakukan respisifikasi model. Modifikasi model dilakukan dengan melihat nilai modification indeces (MI). Tabel 2 menunjukkan hasil respesifikasi model yaitu terdapat empat kriteria GOF yang fit dan tiga kriteria marginal fit sehingga, dapat dilakukan uji hipotesis.

Analisis uji model dan hipotesis SEM diolah menggunakan software AMOS untuk menguji hipotesis. Berdasarkan nilai estimasi dan nilai p pada Tabel 3, seluruh variabel memiliki pengaruh yang signifikan.

Tabel 2.

Nilai goodness-of-fit model struktural setelah respesifikasi

\begin{tabular}{cccc}
\hline Good of Fit Index & \multicolumn{1}{c}{ Cut-off Value } & Hasil Model & Keterangan \\
Chi Square & \multicolumn{2}{c}{ Absolute Fit Indices } & \\
GFI & $\geq 0,90,395$ & 2,225 & Fit \\
RMSEA & $\leq 0,08$ & 0,739 & Tidak Fit \\
RMR & $\leq 0,05$ & 0,067 & Fit \\
& Incremental Fit Indices & Tidak Fit \\
CFI & $\geq 0,90$ & 0,106 & \\
TLI & $\geq 0,90$ & 0,853 & Marginal Fit \\
IFI & $\geq 0,90$ & 0,864 & Marginal Fit \\
& Parsimony Fit Indices & Fit Fit \\
PGFI & $0,5-1$ & 0,661 & Fit \\
PNFI & $0,6-0,9$ & 0,728 & \\
\hline
\end{tabular}

Tabel 3.

Uji hipotesis SEM

\begin{tabular}{|c|c|c|c|c|c|c|}
\hline \multicolumn{4}{|c|}{ Hipotesis } & Estimate & $P$ & Keterangan \\
\hline 1 & $\begin{array}{c}\text { Halal } \\
\text { Awareness }\end{array}$ & $\rightarrow$ & Sikap & 0,176 & 0,035 & Signifikan \\
\hline 2 & Religiosity & $\rightarrow$ & Sikap & 5,493 & $* * *$ & Signifikan \\
\hline 3 & $\begin{array}{c}\text { Sertifikasi } \\
\text { Halal }\end{array}$ & $\rightarrow$ & Sikap & 0,457 & $* * *$ & Signifikan \\
\hline 4 & $\begin{array}{c}\text { Pemasaran } \\
\text { Halal }\end{array}$ & $\rightarrow$ & Sikap & 0,169 & 0,008 & Signifikan \\
\hline 5 & $\begin{array}{c}\text { Norma } \\
\text { Subjektif }\end{array}$ & $\rightarrow$ & $\begin{array}{l}\text { Niat } \\
\text { Beli }\end{array}$ & 0,347 & $* * *$ & Signifikan \\
\hline 6 & Sikap & $\rightarrow$ & $\begin{array}{l}\text { Niat } \\
\text { Beli }\end{array}$ & 0,547 & $* * *$ & Signifikan \\
\hline
\end{tabular}

Variabel yang memiliki nilai signifikansi kurang dari 0,05 terhadap variabel sikap adalah halal awareness, religiosity, halal certification, dan halal marketing. Hal ini dapat dikatakan bahwa halal awareness, religiosity, halal certification, dan halal marketing dapat mempengaruhi sikap konsumen terhadap produk kosmetik halal. Lebih 
lanjut, variabel yang memiliki nilai signifikansi kurang dari 0,05 terhadap variabel niat beli adalah norma subjektif dan sikap. Hal ini dapat dikatakan bahwa norma subjektif dan sikap konsumen dapat mempengaruhi niat beli produk kosmetik halal. Nilai estimasi seluruh variabel memiliki nilai yang positif, yang artinya bahwa adanya pengaruh yang seaarah antara kedua variabel bahwa semakin positif sikap yang dimiliki konsumen, maka akan semakin tinggi pula niat beli produk kosmetik halal.

\section{Diskusi}

Berdasarkan hasil analisis SEM, didapatkan hasil bahwa seluruh variabel memiliki pengaruh yang signifikan. Konstruk halal awareness menghasilkan nilai p-value kurang dari taraf signifikansi yaitu sebesar 0,05 dan arah pengaruh halal awareness terhadap sikap adalah positif dan. Oleh karena itu, hipotesis 1 diterima, yang memiliki arti bahwa kesadaran konsumen yang tinggi akan kehalalan sebuah produk kosmetik akan membentuk sikap positif konsumen terhadap produk kosmetik halal.

Konstruk religiosity menghasilkan $p$-value kurang dari taraf signifikansi yaitu sebesar 0,05 sehingga dan arah pengaruh religiosity terhadap sikap adalah positif sehingga, hipotesis 2 diterima. Apabila seorang individu memiliki tingkat religiusitas yang semakin intrinsik, maka akan semakin positif pula sikap yang dimiliki oleh konsumen. Individu dengan religius intrinsik menganggap bahwa agama merupakan fokus utama dalam kehidupan [10].

Konstruk sertifikasi halal menghasilkan p-value kurang dari taraf signifikansi yaitu sebesar 0,05 dan arah pengaruh sertifikasi halal terhadap sikap adalah positif sehingga, hipotesis 3 diterima. Apabila sebuah produk kosmetik memiliki sertifikasi halal dan menampilkan logo halal pada produknya, maka akan semakin positif pula sikap yang dimiliki oleh konsumen. Sertifikasi halal mengacu pada pengakuan resmi bahwa proses persiapan, pemotongan, pembersihan, penanganan, dan praktik manajemen yang relevan lainnya telah memenuhi standar halal.

Konstruk halal marketing menghasilkan p-value p-value kurang dari taraf signifikansi yaitu sebesar 0,05 dan arah pengaruh halal marketing terhadap sikap adalah positif sehingga, hipotesis 4 diterima. Semakin sebuah produk kosmetik mengikuti hukum dan prinsip-prinsip Islam dalam merancang pemasarannya, maka akan semakin positif pula sikap yang dimiliki oleh konsumen. Halal marketing mengacu pada periklanan dan pemasaran yang digunakan perusahaan untuk memasarkannya kepada konsumen.

Konstruk norma subjektif menghasilkan kurang dari taraf signifikansi yaitu sebesar 0,05 dan arah pengaruh norma subjektif terhadap niat beli adalah positif sehingga, hipotesis 5 diterima. Semakin tinggi persepsi konsumen bahwa terdapat tekanan dalam lingkungannya untuk menggunakan produk kosmetik halal, maka akan semakin positif pula niat beli yang dimiliki. Tekanan yang dirasakan konsumen berasal dari preferensi keluarga atau teman dekat konsumen terhadap produk kosmetik halal. Dengan begitu, konsumen akan memiliki preferensi yang sama karena tidak terdapat penolakan dalam lingkungannya.

Konstruk sikap menghasilkan p-value kurang dari taraf signifikansi yaitu sebesar 0,05 dan arah pengaruh norma subjektif terhadap niat beli adalah positif sehingga, hipotesis 6 diterima. Semakin positif sikap yang dimiliki oleh konsumen pada kosmetik halal, maka akan semakin positif pula niat beli yang dimiliki. Sikap mengacu pada evaluasi negatif atau positif konsumen pada suatu produk.

\section{Implikasi Manajerial}

Berdasarkan analisis yang telah dilakukan didapat hasil bahwa seluruh variabel penelitian diterima. Terdapat beberapa strategi yang dapat diterapkan oleh perusahaan kosmetik halal. Hasil penelitian menyatakan bahwa halal awareness dan religiosity dapat membentuk sikap positif serta niat beli produk kosmetik halal. Strategi yang dapat dilakukan oleh perusahaan adalah dengan menampilkan bahan-bahan yang terkandung dalam produk kosmetik.

Hasil penelitian menyatakan bahwa pemasaran halal dapat membentuk sikap positif konsumen. Strategi yang dapat diterapkan yaitu dengan melakukan branding sebagai produk kosmetik halal. Branding yang dilakukan dapat melalui tagline, kemasan, dan layanan yang diberikan. Strategi lainnya yang dapat diterapkan yaitu dengan bekerjasama dengan beaty vloger atau selebgram untuk melakukan review produk

Hasil penelitian menyatakan bahwa sertifikasi halal dapat membentuk sikap positif serta niat beli produk kosmetik halal sehingga, perusahaan perlu mendaftarkan produknya ke LPPOM MUI untuk mendapatkan sertifikasi halal dan menampilkan logo halal asli pada kemasan produk. Perusahaan juga perlu memenampilkan logo halal pada setiap kegiatan promosi yang dilakukan. Variabel lainnya yang dapat membentuk niat beli produk kosmetik halal yaitu norma subjektif. Rekomendasi strategi yang diberikan yaitu dengan mengadakan event giveaway berhadiah di media sosial. event giveaway dirancang agar dapat melibatkan teman atau keluarga konsumen.

\section{KESIMPULAN/RINGKASAN}

Penelitian ini menunjukkan bahwa halal awareness, religiosity, sertifikasi halal, dan pemasaran halal berpengaruh positif terhadap sikap konsumen produk kosmetik halal. Hubungan dari keempat faktor tersebut adalah positif, yang berarti bahwa semakin baik tingkat religiosity, sertifikasi halal, dan pemasaran halal maka akan semakin membentuk sikap yang positif konsumen produk kosmetik halal. Penelitian ini menemukan bahwa niat beli produk kosmetik halal dipengaruhi oleh norma subjektif dan sikap konsumen. Konsumen yang memiliki persepsi bahwa terdapat tekanan sosial untuk menggunakan produk kosmetik halal cenderung memiliki niat beli produk kosmetik halal di masa mendatang. Tekanan sosial yang dirasakan konsumen berasal dari keluarga dan teman terdekat. Terdapat beberapa strategi yang dapat diterapkan oleh perusahaan kosmetik halal untuk meningkatkan pendapatan serta untuk memenangkan persaingan. Penelitian ini menggunakan metode survei, untuk penelitian selanjutnya disarankan untuk menggunakan metode eksplorasi. 


\section{DAFTAR PUSTAKA}

[1] Allied Market Research, "Report Overview Global Opportunity Analysis and Industry Forecast, 2014 - 2022,” 2016.

[2] PT Citra Cendekia Indonesia, "Perkembangan Pasar Industri Kosmetik Di Indonesia, 2010 - 2015," 2016. [Online]. Available: http://cciindonesia.com/2016/06/17/perkembangan-pasar-industri-kosmetik-diindonesia-2010-2015/.

[3] S. Lada, G. H. Tanakinjal, and H. Amin, "Predicting Intention to Choose Halal Products Using Theory of Reasoned Action," Int. J. Islam. Middle East. Financ. Manag., pp. 66-76, 2009.

[4] F. Pratiwi, "Industri Kosmetik Halal Diprediksi Tumbuh Rata-Rata 10 Persen," 2015

[5] T. Reuters, "State of The Global Islamic Economy Report 2016/17," Dubai, 2016.

[6] A. Mukhtar and M. M. Butt, "Intention to Choose Halal Products: The Role of Religiosity," J. Islam. Mark., pp. 106-120, 2012.

[7] H. M. Awan, A. N. Siddiquei, and Z. Haider, "Factors Affecting Halal Purchase Intention - Evidence from Pakistan's Halal Food Sector,' Manag. Res. Rev., 2015.
[8] F. Hassandoust and R. L. Kazerouni, "Behavioral Factors Influencing Virtual Knowledge Sharing: Theory of Reasoned Action," J. Appl. Res. High. Educ., pp. 116-134, 2011.

[9] Y. A. Aziz and N. V. Chok, "The Role of Halal Awareness, Halal Certification, and Marketing Components in Determining Halal Purchase Intention Among Non-Muslims in Malaysia," J. Int. Food Agribus. Mark., pp. 683-712, 2013.

[10]N. Essoo and S. Dibb, "Religious Influences on Shopping Behaviour: An Exploratory Study," J. Mark. Manag., pp. 683-712, 2004.

[11]G. W. Allport and J. M. Ross, "Personal Religious Orientation And Prejudice," J. Personal. Soc. Psychol. 1967, pp. 432-443, 1967.

[12]S. Arif and R. Ahmad, "Food Quality Standards in Developing Quality Human Capital: An Islamic Perspective," African J. Bus. Manag., pp. 3938-3948, 2011

[13] T. Islam and U. Chandrasekaran, "Halal Marketing: Growing the Pie," Int. J. Manag. Res. Rev., pp. 3938-3948, 2013.

[14] S. Rajagopal, S. Ramanan, R. Visvanathan, and S. Satapathy, "Halal Certification: Implication for Marketers in UAE," J. Islam. Mark., pp. 138-153, 2011. 